\title{
Oral Creatine Supplementation in Mice Induces Hepatic Protein Overload.
}

\section{J. A. Duarte}

M. J. Neuparth

J. M. C. Soares

Faculty of Sport Sciences and Physical Education University of Porto

Portugal

https://doi.org/10.5628/rpcd.01.03.40

\section{ABSTRACT}

Oral creatine supplementation is increasingly practised by athletes to improve performance in various types of exercise. While many studies have investigated the effects on skeletal muscle, little is known about the effects of creatine ingestion on hepatic tissue. In this study, a group of mice received creatine supplementation for a period of six days and some hepatic parameters were compared with a control group. The creatine supplemented animals showed a pronounced gain in body weight probably due to water retention. Their hepatic protein content was increased by $23 \%$, and liver phosphocreatine concentration showed a similar increase. Among the hepatic enzymes studied, GOT decreased and GPT showed a tendency to increase; both changes can be explained by metabolic alterations due to overload of the amino acid components of creatine. ATP concentrations and CK activity did not change after creatine feeding. The results speak in favour of a moderate hepatic protein overload with concomitant metabolic alterations after creatine supplementation.

Keywords: Creatine supplementation, Liver, Water retention.

\author{
H.-J. Appell \\ Institute of Sport Orthopedics \\ German Sport University Cologne \\ Germany
}

RESUMO

A suplementação oral de creatina em ratinhos induz sobrecarga hepática proteica.

Com o intuito de melhorar o rendimento desportivo, a suplementação de creatina tem sido uma prática vulgar entre atletas de diferentes modalidades. Apesar de numerosos, os trabalhos experimentais realizados sobre o tema são sobretudo direccionados para o músculo esquelético, conhecendo-se ainda muito mal as repercussões da ingestão de creatina no tecido hepático. Com o objectivo de estudar os seus efeitos sobre aquele tecido, um grupo de ratinhos foi submetido a um suplemento de creatina, por via oral, durante seis dias, no fim do qual foram avaliados alguns parâmetros hepáticos e comparados com os de um grupo controlo. Os animais sujeitos à acção da creatina mostraram um acentuado incremento do seu peso corporal, provavelmente explicado pela retenção hídrica. O conteúdo total de proteínas assim como as concentrações de fosfocreatina no fígado destes animais, comparativamente aos animais do grupo controlo, apresentaram aumentos similares na ordem dos 23\%. No que diz respeito à actividade das enzimas hepaticas estudadas, a GOT diminuiu, enquanto que a GPT mostrou uma tendência para aumentar. Estas modificações na concentração de substratos $e$ na actividade enzimática podem ser explicadas pelas alterações metabólicas induzidas pela sobrecarga de aminoácidos componentes da creatina. As concentrações de ATP e a actividade da CK não mostraram qualquer alteração comparativamente aos animais não tratados. Os resultados sugerem que o suplemento de creatina induz sobrecarga hepática de proteínas com alterações concomitantes do metabolismo deste tecido.

Palavras-chave: suplemento de creatina, fígado, retenção de água. 


\section{INTRODUCTION}

Among the nutritional supplemental substances that are assumed to possess a performance enhancing potential, creatine monohydrate has become one of the most popular in the recent past $(4,5,9,11)$. Oral creatine supplementation improves performance during high intensity short duration exercise $(1,3)$, but has little effect during prolonged submaximal exercise $(2,14)$. It has been shown that $\mathrm{Cr}$ supplementation leads to an increase of total creatine $(\mathrm{Cr})$ and phosphocreatine (PCr) content in human skeletal muscle (11) and consequently to a higher rate of adenosine triphosphate (ATP) resynthesis (6).

Recent studies have described some side effects of oral creatine supplementation on kidney function (13), but little is known about the effects of this substance on hepatic tissue. It is known that a large fraction of amino acids of ingested proteins is catabolized by hepatic enzymes (15). Therefore, protein loading induced by $\mathrm{Cr}$ ingestion could highly demand the hepatic metabolism. The aim of the present study was to investigate the effect of short-term oral creatine ingestion on some markers of liver metabolism.

\section{METHODS}

Fifteen male Charles River mice aged 6 weeks were divided into two groups: Control group $(n=6$, body weight $=36.2 \pm 1.55 \mathrm{~g})$ and creatine supplementation group (CrSup, $n=9$, body weight $=35.6 \pm 1.25 \mathrm{~g}$ ). The experiments were conducted in accordance with pertinent guidelines for care and use of laboratory animals. All mice received standard laboratory food and water ad libitum and were not submitted to any exercise.

The CrSup mice received creatine monohydrate (Creatine, Prolab, USA) diluted in water in order to provide a daily dosage of $0.3 \mathrm{mg}$ per $\mathrm{g}$ of body weight for a period of six days. The dosage was chosen according to reports that a daily $20 \mathrm{~g}$ Cr supplementation in adult humans (70kg) over six days results in increased muscle $\mathrm{Cr}$ concentrations (8, 11). The Cr concentration diluted in water was based on previous regular observations that mice drink 10-11 ml/day.

All animals were sacrificed by cervical dislocation at the end of the experimental period. Body weight was measured and the liver was removed for biochemical analysis. The liver was homogenised in Triton X-100 (Boehringer Mannheim) in $0.1 \% 50 \mathrm{mM}$ phosphate buffer at pH 7.4 (Sigma Chemicals) with a SS3 homogenizer. Hepatic enzyme activities (Glutamate oxaloacetate transaminase-GOT, Glutamate pyruvate transaminase-GPT, and creatine kinase-CK) were measured spectrophotometrically (Genesis 5) using commercial kits (Irlandox cat n ${ }^{\circ}$ AS 101 for GOT, Irlandox cat $\mathrm{n}^{\circ} \mathrm{AL} 100$ for GPT, and Boehringer Mannheim cat $n^{\circ} 1087533$ for CK). ATP and phosphocreatine concentrations were determined by analytical procedures described earlier (7). The hepatic protein content was assayed by the Biuret method (Irlandox; cat $\mathrm{n}^{\mathrm{O}} \mathrm{TP} 245$ ).

All values were expressed as means with standard deviations. Statistical differences between the groups (for biochemical data) and within the groups (for body weight) were analyzed with the Student t-test with a significance level at $\mathrm{p}<0.05$.

\section{RESULTS}

Starting with a similar body weight of $36.3 \pm 1.5 \mathrm{~g}$ (control) and 35.6 $\pm 1.3 \mathrm{~g}$ (CrSup), respectively, the CrSup group showed a significant gain $(+7 \%)$ in body weight $(38.0 \pm 1.2 \mathrm{~g})$, while the weight gain $(+3 \%)$ in controls $(37.4 \pm 1.3 \mathrm{~g})$ was not significant. Hepatic enzymatic activities are shown in Table 1: GOT activity was $10 \%$ lower in the CrSup group compared to controls $(\mathrm{p}<0.05)$. Although not being statistically significant, some $(12 \%)$ tendency for a higher GPT activity appeared after Cr supplementation. The hepatic CK activity did not change with $\mathrm{Cr}$ supplementation.

Table 1 Enzymatic activities (U/g of tissue) of GOT, GPT and CK.

\begin{tabular}{lccc} 
Group & GOT & GPT & CK \\
\hline Control & $28.58 \pm 4.76$ & $25.81 \pm 10.63$ & $3.74 \pm 2.05$ \\
CrSup & $25.98 \pm 6.75^{*}$ & $28.85 \pm 7.55$ & $3.69 \pm 1.59$
\end{tabular}

${ }^{*} p<0.05$ vs. Control

As a result of $\mathrm{Cr}$ supplementation, the hepatic protein content was $23 \%$ higher as compared to controls (Table 2). While liver ATP concentration did not change, a $22 \%$ higher $\mathrm{PCr}$ concentration was found in the CrSup group. 
Table 2 Protein content [\%], ATP and PCr concentrations ( $\mathrm{mmol} / \mathrm{kg}$ ).

\begin{tabular}{lccc} 
Group & \% proteins & ATP & $\mathrm{PCr}$ \\
\hline Control & $16.8 \pm 1.6$ & $4.75 \pm 1.24$ & $1.16 \pm 0.18$ \\
CrSup & $20.7 \pm 5.5^{*}$ & $4.58 \pm 1.08$ & $1.41 \pm 0.31^{*}$
\end{tabular}

${ }^{*} p<0.05$ vs. Control

\section{DISCUSSION}

The Cr supplemented group showed a significant gain in body weight that was more than twofold of the (n.s.) weight gain in the control group. While some of the changes could depend on the growing process of both groups consisting of young mice, the magnitude of increase in body weight in the CrSup group should be attributed to the $\mathrm{Cr}$ supplementation. Such an effect has been reported in various studies on Cr supplementation (for refs. see 11) and can be explained, among other factors (1), by water retention $(10,11)$. Creatine ingestion can result in a protein overload inducing an increase of the colloid osmotic pressure. This increment may reduce renal water clearance as shown by a decreased urinary volume after creatine administration (8).

If a proportional water retention would have been present in hepatic tissue, no percentage increases in liver protein content should have been encountered. However, the CrSup group showed a $23 \%$ higher protein content than the control group, suggesting that a large fraction of polypeptides resulting from the ingested $\mathrm{Cr}$ had been accumulating in the liver. The increased hepatic PCr concentration after Cr supplementation was in a similar magnitude as reported for skeletal muscle and has to be interpreted as an effect of the conversion of $\mathrm{Cr}$ into PCr (11). Because of the absence of any metabolically demanding situation, PCr was not wasted for ATP production, which also is supported by the unchanged ATP concentration and CK activity after Cr supplementation. Ingested $\mathrm{Cr}$ would result in a hepatic overload of its amino acid components (glycine, methionine, arginine), which are utilized for protein and Cr synthesis. Those amino acids can also be catabolized resulting in intermediate glycolytic products like pyruvate (15), which would explain the tendency of an increased GPT activity after Cr supplementation.
On the other hand, GOT activity was lower after $\mathrm{Cr}$ supplementation. Such could be related to an increment of plasma urea concentration observed after $\mathrm{Cr}$ supplementation originating from high arginine concentrations (12). When this amino acid enters into the urea cycle in hepatic tissue, it is transformed into argininosuccinate thereby increasing the amount of oxaloacetate and aspartate (15). Such a balanced increase of these opposite substrates of GOT would result in an adaptively lower activity of this enzyme (15).

The present results speak in favour of a moderate hepatic protein overload with high PCr concentrations and concomitant metabolic adaptations after Cr supplementation. Considering the tendency in competitive sports to abuse such supplements in exaggerated dosages, it remains to be studied in future experiments, whether prolonged or high dosage $\mathrm{Cr}$ supplementation, also under conditions of physical exercise, leads to a dysbalanced metabolic situation in the liver. 


\section{REFERENCES}

1. Balsom PD, Ekblom B, Söderlund K, Sjödin B, Hultman E (1993). Creatine supplementation and dynamic high-intensity intermittent exercise. Scand J Med Sci Sports 3: 143-149. 2. Balsom PD, Harridge SDR, Söderlund K, Sjödin B, Ekblom B (1993). Creatine supplementation per se does not enhance endurance exercise performance. Acta Physiol Scand 149: 521523.

3. Birch R, Noble D, Greenhaff PL (1994). The influence of dietary creatine supplementation on performance during repeated bouts of maximal isokinetic cycling in man. Eur J Appl Physiol 69: $268-270$

4. Casey A, Constantin-Teodosiu D, Howell S, Hultman E, Greenhaff PL (1996). Creatine ingestion favorably affects performance and muscle metabolism during maximal exercise in humans. Am J Physiol 78: E31-E37.

5. Green AL, Simpson EJ, Littlewood JJ, MacDonald IA, Greenhaff PL (1996). Carbohydrate ingestion augments creatine retention during creatine feeding in humans. Acta Physiol Scand 158: 195-202.

6. Greenhaff PL, Bodin K, Söderlund K, Hultman E (1994). The effect of oral creatine supplementation on skeletal muscle phosphocreatine resynthesis. Am J Physiol 266: 725- 730.

7. Harris RC, Hultman E, Nordesjö LO (1974). Glycogen, glycolytic intermediates and high-energy phosphates determined in biopsy samples of musculus quadriceps femoris of man at rest. Methods and variance of values. Scand J. Clin Lab Invest. 33: 109-120.

8. Hultman E, Söderlund K, Timmons JA, Cederbland G, Greenhaff PL (1996). Muscle creatine loading in men. J. Appl Physiol 81: 232-237.

9. Maughan RJ (1995). Creatine supplementation and exercise performance. Int J Sport Nutr 5: 94-101.

10. Mujika I, Chatard JC, Lacoste L, Barale F, Geyssant A

(1996). Creatine supplementation does not improve sprint performance in competitive swimmers. Med Sci Sports Exerc. 28: $1435-1441$.

11. Mujika I, Podila S (1997). Creatine supplementation as an ergogenic aid for sports in highly trained athletes: A critical review. Int J. Sports Med. 18: 491-496.

12. Ööpik V, Timpmann S, Medijainen L, Aleksejeva T (1996). Effect of creatine administration on blood urea level and postexercise glycogen repletion in liver and skeletal muscle in rats. Ann Nutr Metab 40: 359-363.

13. Poortmans JR, Auquier H, Renaut V, Durussel A, Saugy M, Brisson GR (1997). Effect of short-term creatine supplementation on renal responses in men. Eur J. Appl Physiol 76: 566-567. 14. Stroud MA, Holliman D, Bell D, Green AL, MacDonald IA, Greenhaff PL (1994). The effect of oral creatine supplementation on gas exchange and blood lactate accumulation during steady-state incremental treadmill exercise and recovery in man. Clin Sci 87: 707-710.

15. Zubay GL, Parson WW, Vance DE (1995). Amino acid metabolism in vertebrates. In: Principles of Biochemistry.

Dubuque, WmC Brown Communications Inc, pp:517-520. 